\title{
Design and Development of Road Dustbins Based on Urban Functional Areas
}

\author{
Liu lizhen \\ Wenzhou Vocational \& Technical College, Wenzhou. 325035 \\ Email: 1918427983@qq.com
}

Keywords: Dustbin, Design, Analysis

Abstract: This research can increase the enthusiasm of garbage throwers for using classified dustbins, promote garbage classification and recycling more smoothly, raise the recycling rate of garbage and reduce the cost of garbage classification and recycling. Therefore, it is very meaningful and valuable to design classified dustbins.

\section{Introduction}

Citizens can usually see classified dustbins in subways, bus stations, residential areas, tourist attractions and other places. Classified dustbins are closely related to the life of residents. With the promotion of concept of urban garbage classification and recycling, the concept of garbage classification and recycling has gone deep in the hearts of people. However, current classified dustbins fail to play their role and have a number of problems. While appealing to citizens to actively respond to garbage classification, the author thinks that the unreasonable design of classified dustbins has an impact on the effect of garbage classification and recycling.

News materials point it out that the classification and recycling of garbage are propelled by such ways of punishment as "charging fees" and "imposing fines". These practices are still controversial. It is unknown whether these practices can be implemented and produces good effects. In the process of research, it was found that more than $90 \%$ of respondents knew garbage classification and recycling, but seldom put it into practice in life. Many respondents said they did not know how to use classified dustbins or they found it inconvenient to use classified dustbins. Apart from meeting aesthetic needs in appearance, user-friendly and pleasant classified dustbins should put more emphasis on satisfying emotional needs.

\section{Research status of domestic classified dustbins}

At present, classified dustbins in the public places of China are divided into the following categories, including fiberglass dustbins, steel dustbins, plastic dustbins and steel wood dustbins. Now, the market has the largest number of fiberglass dustbins which are characterized by anti-corrosion, anti-theft and no rust. With steel frame, steel wood dustbins are decorated with battens outside. With high durability, steel dustbins can be recycled, but they are apt to rust. Plastic dustbins are easy to process, but they are prone to aging outdoors. Classified dustbins are mainly square and cylindrical. In addition, some dustbins with cartoon figures have rather traditional 
modelling. The colors of classified dustbins on the market are not classified, which fails to identify the specific meanings of different colors. Harmful waste is put into red dustbins; unrecyclable garbage is put into grey dustbins; recyclable garbage is put into blue dustbins; household garbage is put into green dustbins. as shown in Fig 1.

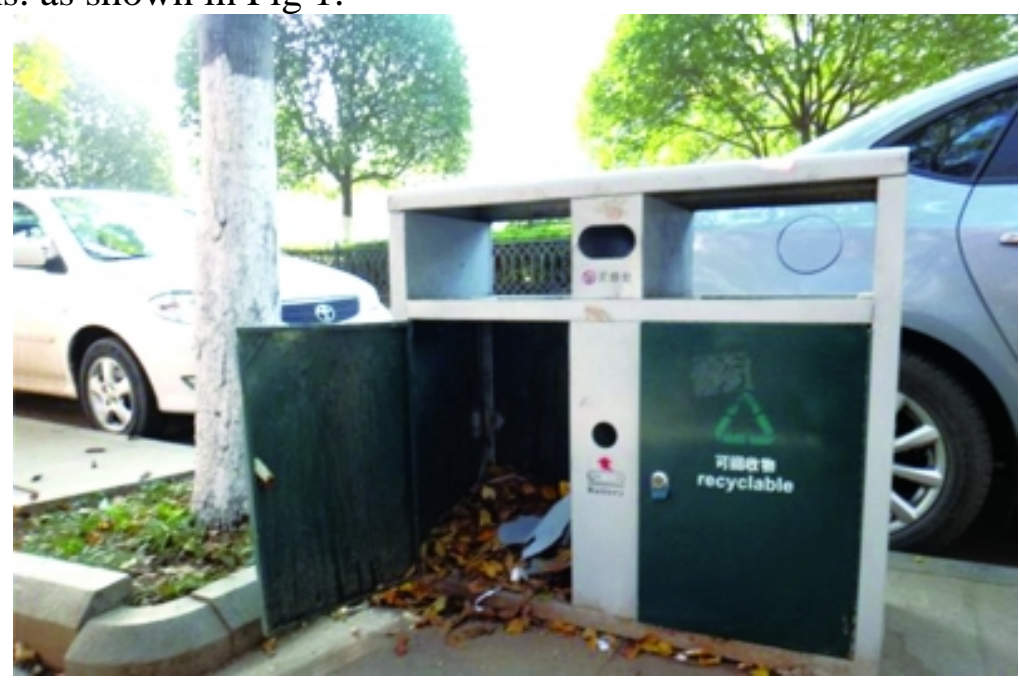

Fig. 1 Reference diagram (I)

\section{Design content}

The research content of this subject mainly contains investigation, analysis and conclusion. This research investigates classified dustbins on the market and conducts a survey on users using classified dustbins. The research content of products involves the modelling, materials, colors, classification signs and other aspects of classified dustbins. The research content of users includes user experience and places needing improvement. In addition, this research analyzes research content, designs the size of products according to ergonomic theory, conducts an analysis on the advantages and disadvantages of classified dustbins in the course of use according to existing classified dustbins, comes to a conclusion and makes suggestions on the design of classified dustbins on the basis of market investigation and analytical data.

This research mainly has the following innovation points:

(1) Apply unique modelling to design classified dustbins, breaking the modelling characteristics of traditional classified dustbins and make products more novel and highlighted.

(2) Pay attention to details. This research starts with the classification signs of classified dustbins for improved design. Traditional classification signs only stick a picture with a sign simply and fail to work as signs. Signs can enable users to clearly identify the categories of garbage.

(3) Combine with people-oriented thought, add some new functions like glowing at night and lighting based on classified garbage, and make original products more innovative.

Human dimensions related to dustbins

Table 1 shows the investigation data of users. 
Table 1 Human dimensions related to dustbins

\begin{tabular}{|l|l|l|l|l|l|l|}
\hline \multicolumn{2}{|c|}{ Dimension } & \multicolumn{3}{c|}{ Male } & \multicolumn{3}{c|}{ Female } \\
\cline { 2 - 7 } & $5 \%$ & $50 \%$ & $95 \%$ & $5 \%$ & $50 \%$ & $95 \%$ \\
\hline Elbow height of standing position & 954 & 1024 & 1096 & 899 & 960 & 1023 \\
\hline $\begin{array}{l}\text { Functional hand height of standing } \\
\text { position }\end{array}$ & 680 & 741 & 801 & 650 & 704 & 757 \\
\hline $\begin{array}{l}\text { Functional height of raising both hands } \\
\text { of standing position }\end{array}$ & 1869 & 2003 & 2138 & 1741 & 1860 & 1976 \\
\hline Hand breadth & 70 & 80 & 90 & 60 & 70 & 80 \\
\hline Hand length & 165 & 180 & 197 & 150 & 165 & 180 \\
\hline
\end{tabular}

Human dimensions related to dustbins: Elbow height, functional hand height of standing position, functional height of raising both hands of standing position, hand length and hand breadth, as shown in Fig 2.

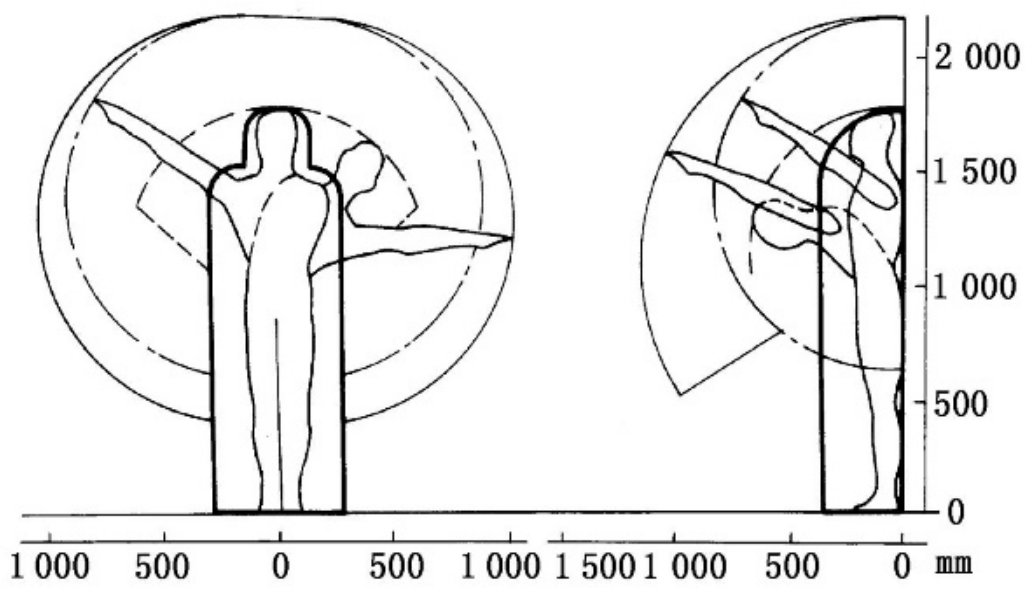

(a)

(b)

Fig. 2 Functional height of raising both hands of standing position

\section{Users' psychological analysis of products}

(I) Throw garbage into dustbins easily. The most basic requirement of using dustbins for users is to throw garbage easily. As a result, it is one of requirements for designing dustbins. The open mode of dustbins contains upper and side openings. No matter which open mode a dustbin has, people should easily throw garbage into the dustbin at the distance of $30 \mathrm{~cm}$ to $50 \mathrm{~cm}$ from the dustbin. Classified dustbins in public places have two forms, including foot-pedal cover lifting and pushing plate. However, foot-pedal dustbins are easy to damage after being used many times. Therefore, foot-pedal dustbins are suitable for indoor use rather than public use. When using push-plate dustbins, people will not completely throw garbage into dustbins for fear of getting injured and other factors, leading to phenomena like garbage overflow. Therefore, the opening design of classified dustbins has to pay attention to practicability.

(II) Clear up garbage easily. Dustmen need to clear up garbage in classified dustbins every day. Therefore, garbage should be thrown into dustbins more easily. Built-in dustbins should avoid blind angles and be covered with plastic bags, which can reduce the time of clearing up garbage. 
Classified dustbins on the market adopt the method of combining outer barrel with inner barrel. Inner barrels are covered with a plastic bag. Dustmen can directly take out garbage bags from dustbins when clearing up garbage.

(III) Safety principle. Users need to keep close contact with dustbins when throwing garbage in daily life. As a result, the safety of dustbins is of great importance. The materials of dustbins should be corrosion-resistant and have no ignition point. The modelling of dustbins should avoid sharp edges in case people throwing garbage get hurt.

\section{Design scheme}

According to texture, classified dustbins on the market can be divided into stainless steel, fiberglass, ceramic, plastic, wooden, iron, steel wood, steel, galvanized, paper pulp and other dustbins. Among them, stainless steel dustbins are solid and easy to clean. However, they are easily stolen with high production cost. Plastic dustbins are commonly used because of low cost and simple production. However, they are easy to damage and fade due to exposure to the weather. Iron dustbins are recyclable, but they are easy to rust. Fiberglass dustbins can have optionally customized modelling and select multiple colors, but they are easy to damage in cold weather. The texture of products is up to the material selection of products. Different materials will present different effects, as shown in Fig3 and Fig 4.
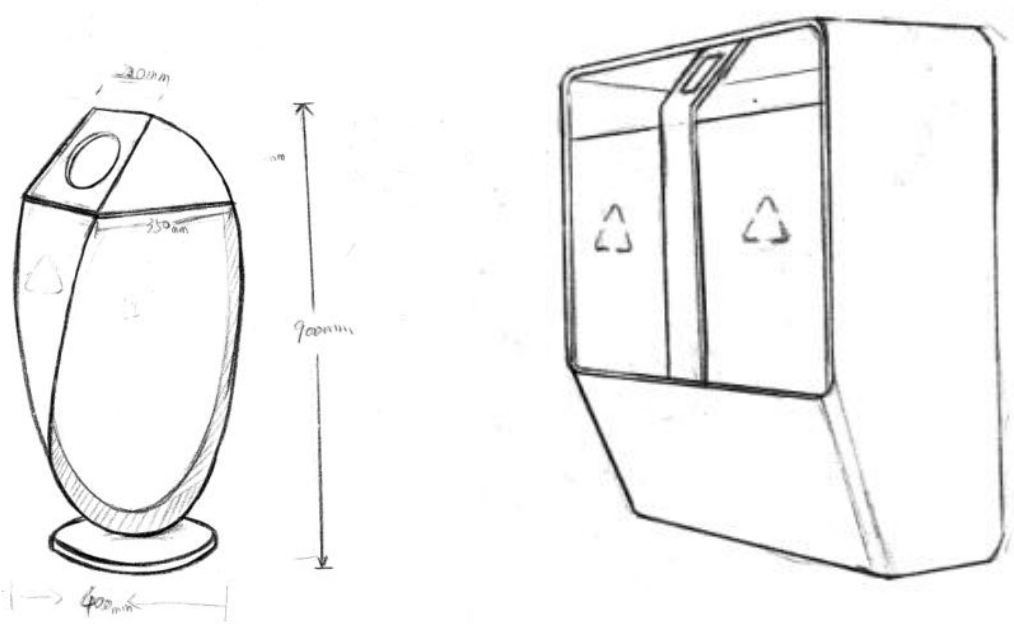

Fig. 3 Texture effect Fig. 4 Irregular effect

Classified dustbins are complementary to people's environmental consciousness. If people have weak environmental consciousness, the setup of classified dustbins will make no sense. On the contrary, the popularity and setup of classified dustbins can also strengthen people's environmental consciousness and make users fully understand the importance and necessity of garbage classification, as shown in Fig 5. 


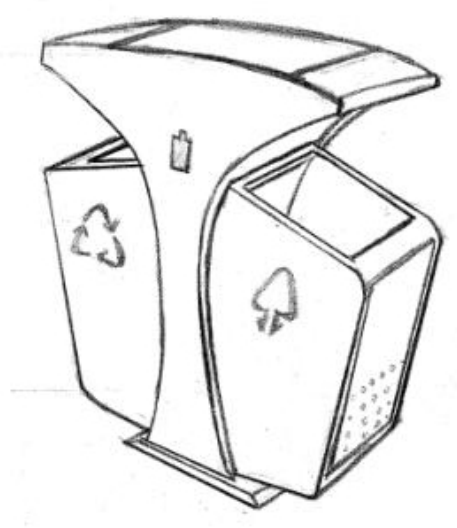

Fig. 5 Shape of environmental protection

The significance of designing classified dustbins lies in enabling people to have a clear understanding of garbage classification to a certain degree and equivalently improving some dustbins with unreasonable design in cities. The design of classified dustbins helps users to classify garbage because of the design of dustbins, brings positive experience to users and makes people produce a sense of achievement in the process of using dustbins so as to gradually change some drawbacks in the current garbage classification of China and protect the environment where we live, as shown in Fig 6.

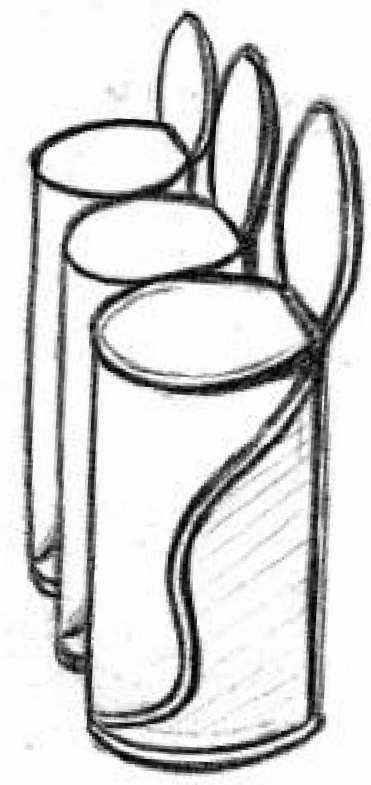

Fig. 6 Sketch design

Recyclable garbage cannot be recycled. For instance, some waste scraps of paper and cartons can be recycled and reused to make other things. Mixed garbage will cause great damage to our land and water due to the mixture of harmful, household and other garbage. Classified dustbins can be seen everywhere in our daily life. According to daily use, we can come to such a conclusion that the 
reasonable design of classified dustbins has a direct impact on garbage recycling and our living environment. Thus, the author will design more reasonable classified dustbins to improve people's environmental consciousness and create a better living environment, as shown in Fig 7.

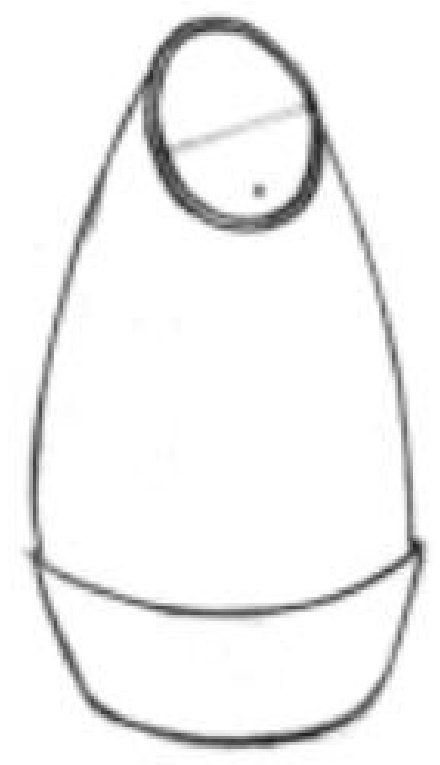

Fig. 7 Sketch design

\section{Research on existing classified dustbins}

Now, classified dustbins can be seen everywhere on the market. Past single-barrel dustbins are changed into current classified dustbins, showing that people's environmental consciousness has become stronger and stronger with the development of the society.

In some public places, we will usually see such classified dustbins, most of which can be divided into recyclable dustbins, unrecyclable dustbins and the harmful dustbins with the most inconspicuous design. However, we can see that dustbins are carefully classified in Japan. Each type of garbage has its dustbins so that people do not need to think about throwing garbage into the right dustbin. Various colors of classified dustbins are even placed on the streets of some countries. In addition, classified dustbins themselves can play the role of garbage classification. For example, the setup of harmful dustbins can enable people to learn about how much damage caused by harmful substances to nature. Scrap paper and plastic bottles in recyclable dustbins can be recycled and reused to display their value. Therefore, the setup of classified dustbins gives garbage a real home.

\section{Design significance}

With the rapid development of the society, garbage classification in many foreign countries has been very perfect. For instance, classified dustbins in Japan have many categories. Every dustbin has a clear sign to remind users to throw garbage correctly. Garbage bags are even distributed to every family. There are various classified patterns on garbage bags. For example, kitchen garbage is a sign of fish, which makes people clear at a glance. However, China is very backward in garbage classification. Most of dustbins in public places are classified into recyclable and unrecyclable garbage. Signs are also extremely common. In addition, people are totally at a loss about garbage 
classification and finally have to throw garbage together helplessly. In the aspect of garbage classification and recycling, users throw harmful and recyclable garbage together due to the unreasonable design of classified dustbins.

Garbage classification and recycling can reduce a lot of pollution. Discarded batteries contain metallic mercury, cadmium and other toxic substances, which will cause serious harm to humans. For instance, a button battery can pollute 600,000 liters of water which is equal to the lifelong water consumption of a person. A battery rotting in the ground can deprive $1 \mathrm{~m} 2$ of land of its utilization value. Recyclables can be recycled and applied elsewhere. For example, one ton of waste plastics can refine 600 kilograms of diesel oil, recycle 1,500 tons of waste paper and avoid cutting down trees used for producing 1,200 tons of paper, which protects the environment and saves resources.

\section{Conclusion}

Design takes into account people's experience of using products and avoids the negative effects of people on products. The modelling, materials, colors and functions of classified dustbins should be designed according to humanistic factors including users' actual needs, easy operation, using experience and so on. The innovative design of products is further understood through investigation on existing classified dustbins and thoughts on products after investigation. Now, an increasing number of people start to pay attention to the value of products and whether a product can reflect its meaning after being designed. Therefore, the delivery of product value receives great concern and is highly valued. The value of classified dustbins is mainly reflected in their humanized consideration.

\section{References}

[1]Yin Jun Zhang,Zheng Jie Lu,Jian Bo Nie,Hao Ran Wang. Design of Intelligent Garbage Can[J]. Applied Mechanics and Materials,2015,3844(741).

[2]Daeyoung Yu,Joseph H.W. Lee,Colin K.C. Wong. Stormwater overflow in stepped channel[J]. Journal of Hydro-environment Research,2008,2(2).

[3]Oseni M Millamena. Replacement of fish meal by animal by-product meals in a practical diet for grow-out culture of grouper Epinephelus coioides[J]. Aquaculture,2002,204(1).

[4] Wayne L. Turnberg. Community Syringe Collection and Disposal Policies in 16 States[J]. Journal of the American Pharmaceutical Association,2002,42(6).

[5]Yeasmin Farzana,Luby Stephen P,Saxton Ronald E,Nizame Fosiul A,Alam Mahbub-Ul,Dutta Notan Chandra,Masud Abdullah-Al,Yeasmin Dalia,Layden Anita,Rahman Habibur,Abbott Rachel,Unicomb Leanne,Winch Peter J. Piloting a low-cost hardware intervention to reduce improper disposal of solid waste in communal toilets in low-income settlements in Dhaka, Bangladesh.[J]. BMC public health,2017,17(1).

[6]Chipeta W C,Holm R H,Kamanula J F,Mtonga W E,de Los Reyes F L. Designing local solutions for emptying pit latrines in low-income urban settlements (Malawi).[J]. Physics and chemistry of the earth (2002),2017,100.

[7]Schneider J H. Selective dissemination and indexing of scientific information.[J]. Science,1971,173(3994).

[8]Ali Peyravi,Safdar Eskandarnejad,Mohammad B. Moghadam. Dual-feed rotor spinning of cotton fiber: trash separation and yarn properties[J]. The Journal of The Textile Institute,2014,105(4).

[9]A. L. Zuikov,G. A. Chepaikin. A model of a high-head bottom spillway with interaction of concentric swirled flows[J]. Hydrotechnical Construction,1987,20(12).

[10]Mohamad Fathhan Arief,Ford Lumban Gaol. DEVELOPING AND EVALUATING PROTOTYPE OF WASTE VOLUME MONITORING USING INTERNET OF THINGS[J]. IOP Conference Series: Materials Science and Engineering,2017,215(1).

[11]Wenxia Guo,Kelley Main. The effectiveness of matching sales influence tactics to consumers' avoidance versus approach shopping motivations[J]. European Journal of Marketing,2017,51(9/10).

[12]Syed V. Ahamed. Chapter 10 - Computer-Aided Knowledge Design and Validation[M].Elsevier Inc.:2017-06-15.

[13]W.C. Chipeta,R.H. Holm,J.F. Kamanula,W.E. Mtonga,F.L. de los Reyes. Designing local solutions for emptying pit latrines in low-income urban settlements (Malawi)[J]. Physics and Chemistry of the Earth,2017. 